\title{
Laju Pertumbuhan Rumput Laut Gracilaria sp Melalui Budidaya IMTA (Integrated Multi Trophic Aquaculture) di Pantai Geger, Nusa Dua, Kabupaten Badung, Bali
}

\author{
Kadek Yudiastuti a*, I Gusti Bagus Sila Dharma a, Ni Luh Putu Ria Puspitha a \\ aProgram Studi Ilmu Kelautan, Fakultas Kelautan dan Perikanan, Universitas Udayana, Kampus UNUD Bukit Jimbaran, Bali 80361, Indonesia \\ * Penulis koresponden. Tel.: +62-821-468-921-99 \\ Alamat e-mail: kadekyudiastuti@gmail.com
}

Diterima (received) 22 Juli 2017; disetujui (accepted) 30 Oktober 2017; tersedia secara online (available online) 31 Oktober 2017

\begin{abstract}
Gracilaria sp is red alga which belong to class rhodophyceae. It can grow in shallow salt water with a general characteristic is having a cylindrical and branched thallus form. Seaweed cultivation can be performed through IMTA (Integrated Multi Trophic Aquaculture) method. The basic principle of cultivation through the IMTA method is utilizing service of the low thropic level species in marine ecosystems, such as shells and seaweed. This method is believed to be able to overcome the environmental problems caused by cultivation activities, such as feces and uneaten feed. This research was perfomed 45 days, from February 25 to April 11, 2017. It was held at Geger Beach, Nusa Dua, Badung Regency, Bali, using a complete randomized design method that consist of three treatments and three repetition for each treatment. Treatment control (T1) consisted of 10 bunches of seaweed 100 grams without the abalone, treatement 2 (T2) consisted of 10 bunches of seaweed 100 grams and 20 abalones and treatement 3 (T3) consisted of 10 bunches of seaweed 100 grams and 40 abalones. The result showed that specific growth rate in Gracilaria sp. was highest in treatment T1, compared to treatment T2 and T3. This was caused by the cage construction of abalone amd the present of small mesh size net to cover the seaweed planting, which made the growth was not optimal. However, the use of a nets system in seaweed cultivation could minimize the loss of thallus. It was proved by the survival rate of seaweed in first, second and third, that is averagely high, ranging from $90 \%$ to $100 \%$. Physical and chemical water quality parameters are also measured, and It showed that the water quality was suitable for the cultivation of both, seaweed and abalone.
\end{abstract}

Keywords: Geger Beach; Gracilaria sp; growth rate; H. squamata; IMTA

\begin{abstract}
Abstrak
Rumput laut Gracilaria sp termasuk dalam kelas rhodophyceae atau ganggang merah, dapat tumbuh dilaut dangkal, dengan ciri-ciri umumnya mempunyai bentuk thallus silindris dan bercabang. Budidaya rumput laut dapat dilakukan melalui budidaya IMTA (Integrated Multi Trophic Aquaculture). Prinsip dasar dari budidaya melalui metode IMTA adalah dengan memanfaatkan layanan spesies tingkat rendah pada ekosistem laut seperti kerang dan rumput laut. Cara ini diyakini dapat mengatasi permasalahan lingkungan akibat kegiatan budidaya seperti kotoran dan pakan yang tidak dimakan. Penelitian ini dilakukan selama 45 hari pada tanggal 25 Februari 2017 hingga 11 April 2017. Penelitian dilaksanakan di Pantai Geger, Nusa Dua, Kabupaten Badung, Provinsi Bali dengan metode Rancangan Acak Lengkap (RAL) dengan menggunakan tiga perlakuan dan tiga pengulangan. Perlakuan kontrol (T1) terdiri dari 10 rumpun rumput laut dengan 100 gram tanpa abalon, perlakuan 2 (T2) terdiri dari 10 rumpun rumput laut dengan 100 gram dan 20 abalon dan perlakuan 3 (T3) terdiri dari 10 rumpun rumput laut dengan 100 gram dan 40 abalon. Hasil penelitian menunjukkan bahwa laju pertumbuhan spesifik pada rumput laut Gracilaria sp tertinggi pada perlakuan T1 (kontrol) dibandingkan dengan perlakuan T2 dan T3. Hal ini disebabkan oleh kontruksi dari pemeliharaan abalon dan ukuran jaring yang kecil menutupi penanaman rumput laut, sehingga pertumbuhannya tidak optimal. Namun penggunaan sistem jaring dapat meminimalkan hilangnya thallus. Hal ini dibuktikan dengan tingkat kelangsungan hidup rumput laut pada perlakuan pertama, kedua dan ketiga, rata-ratanya tinggi berkisar 90\%-100\%. Parameter kualitas air fisika dan kimia yang diukur, dalam hal ini menunjukkan bahwa kualitas air cocok untuk budidaya rumput laut dan abalon.
\end{abstract}

Kata Kunci: Gracilaria sp; H. squamata; IMTA; laju pertumbuhan; Pantai Geger 


\section{Pendahuluan}

Rumput laut merupakan komoditas hasil laut, yang tersebar serta tumbuh di perairan Indonesia dan bernilai ekonomis tinggi sebagai bahan baku industri. Produksi rumput laut di Indonesia menurut statistik FAO (Food and Agriculture Organization) tahun 2013, rumput laut menempati peringkat kedua setelah Cina dengan jumlah produksi sebesar 9,30 juta ton atau $34,60 \%$ dari jumlah produksi rumput laut di dunia (FAO, 2015). Rumput laut merupakan organisme berklorofil sehingga dapat berfotosintesis, tidak dapat dibedakan antara akar, batang dan daun sehingga bagian tubuhnya disebut thallus (uniseluler atau multiseluler) (Ferawati et al, 2014). Jenis rumput laut Gracilaria sp termasuk dalam kelas Rhodophyceae atau alga merah merupakan alga multiseluler, dapat ditemukan di laut dangkal dengan ciri-ciri umumnya mempunyai bentuk thallus rumpun, dan bercabang (Oryza et al., 2017).

Budidaya rumput laut Gracilaria $s p$ secara ekonomis dapat meningkatkan pendapatan (income) dan memberikan nilai tambah bagi masyarakat pembudidaya dengan memanfaatkan lahan produktif untuk menunjang kesejahteraan melalui kegiatan budidaya rumput laut (Hasan et al., 2015). Rumput laut Gracilaria sp merupakan rumput laut penghasil agar yang digunakan dalam berbagai industri seperti makanan, farmasi, biologi dan lain-lain. Pengembangan rumput laut berupa produk olahan industri makanan dalam bentuk jelly, permen, selai dan lain sebagainya dapat meningkatkan perekonomian masyarakat (Sawarni, 2015).

Budidaya dengan pendekatan ekosistem merupakan salah satu solusi dalam menerapkan budidaya berkelanjutan dan ramah lingkungan. IMTA (Integrated Multi Trophic Aquaculture) merupakan sistem budidaya laut dengan pendekatan ekosistem yang memanfaatkan ekosistem laut seperti (kerang dan rumput laut) untuk mengatasi permasalahan lingkungan terhadap penggunaan pakan pada kegiatan budidaya. Perkembangan dengan sistem IMTA telah banyak dilakukan baik dengan dua spesies atau lebih (Putro et al, 2015). Berdasarkan penelitan dari Nobre et al., (2010), penerapan IMTA pada budidaya abalon dengan rumput laut telah menurunkan kadar nitrogen $(\mathrm{N})$ dan fosfor (P) perairan sebesar $44 \%$ dan $23 \%$ dibandingkan dengan budidaya abalon monokultur, sedangkan menurut Abreu et al., (2009), 100 ha Gracilaria dapat menyerap $80 \%$ limbah nitrogen yang dihasilkan oleh 1.500 ton ikan salmon.

Kondisi kualitas perairan merupakan faktor penting dalam mendukung kegiatan budidaya rumput laut, karena air merupakan media yang dapat mempengaruhi kegiatan budidaya rumput laut. Parameter kualitas air yang dapat mempengaruhi pertumbuhan rumput laut antara lain: suhu, salinitas, intensitas cahaya, nutrien, dan kecepatan arus (Tassakka et al., 2014). Ketersediaan nutrien seperti nitrat dan fosfat yang dibutuhkan oleh rumput laut berpengaruh terhadap pertumbuhan rumput laut, Nitrat $\left(\mathrm{NO}_{3}\right)$ merupakan bentuk utama nitrogen di perairan alami dan merupakan nutrien utama bagi makroalga (Masyahoro dan Mappiratu, 2010).

Kerang abalon Haliotis squamata memiliki tingkat kelangsungan hidup yang lebih tinggi terhadap lingkungan serta memiliki tekstur daging yang lebih kenyal, dibandingkan dengan spesies abalon Haliotis asinina. Penerapan budidaya rumput laut Gracilaria $s p$ melalui IMTA yang diintegrasikan dengan kerang abalon (Haliotis squamata) dilakukan untuk meningkatkan nilai produksi rumput laut dan mereduksi limbah hasil budidaya. Rumput laut memiliki peran sebagai biofilter dan penghasil biomassa yang bernilai ekonomis, limbah dalam bentuk feses dan sisa pakan yang tidak termakan oleh kerang abalon dapat menjadikan sumber nutrien yang berguna untuk pertumbuhan rumput laut. Kerang abalon juga dapat memanfaatkan rumput laut sebagai pakan (Troell et al., 2009). Salah satu lokasi perairan yang dijadikan sebagai sentra budidaya rumput laut adalah Pantai Geger, Nusa Dua, Kabupaten Badung, Bali. Rumput laut Gracilaria $s p$ tersebar disekitar perairan Pantai Geger. Oleh karena itu penting untuk dilakukan penelitian mengenai budidaya rumput laut ketika diintegrasikan bersama kerang abalon.

Penelitian ini bertujuan untuk mengetahui laju pertumbuhan, kelulushidupan rumput laut Gracilaria sp ketika dintegrasikan dengan kerang abalon Haliotis squamata dengan padat tebar berbeda dan untuk mengetahui kesesuaian parameter lingkungan fisika dan kimia mendukung budidaya terintegrasi terhadap pertumbuhan rumput laut Gracilaria sp dan kerang abalon H. squamata di Pantai Geger, Nusa Dua, Kabupaten Badung, Provinsi Bali. 


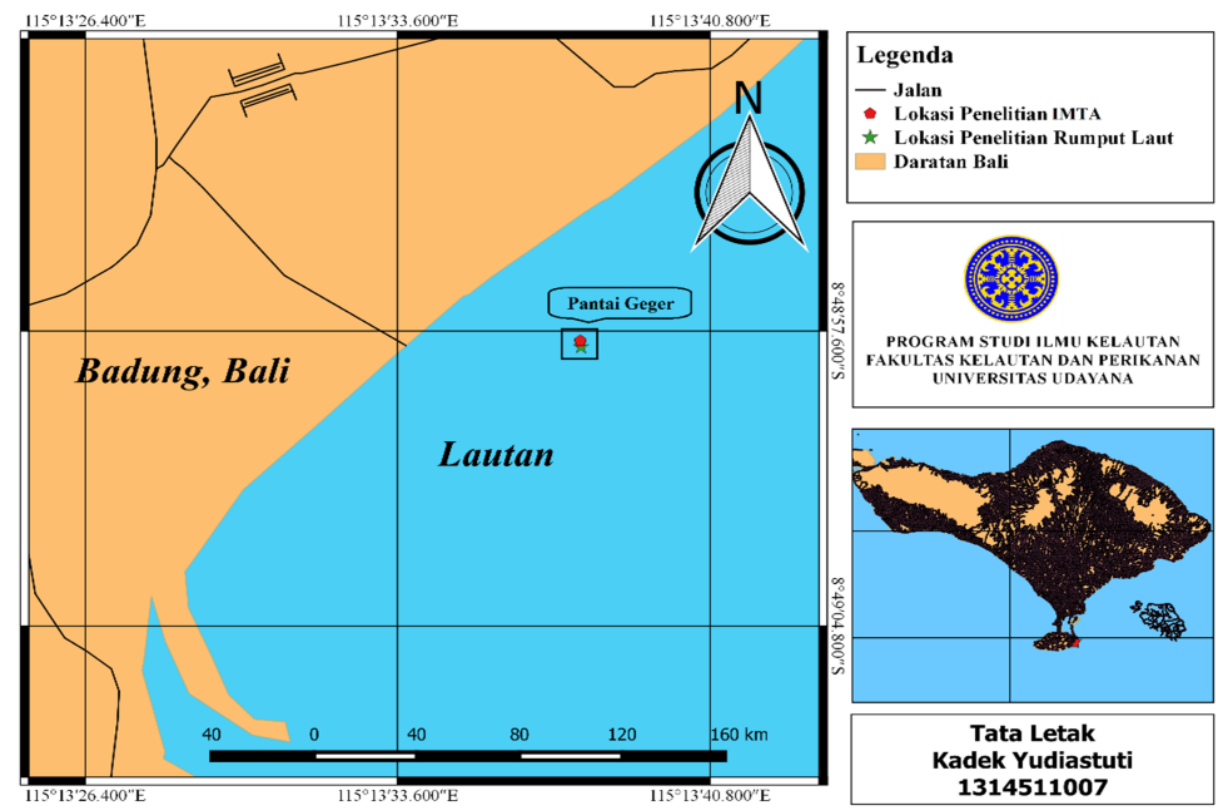

Gambar 1. Peta lokasi penelitian

\section{Metode Penelitian}

\subsection{Waktu dan Tempat}

Penelitian ini dilakukan selama 45 hari pada tanggal 25 Februari 2017 hingga 11 April 2017. Penelitian dilaksanakan di Pantai Geger yang berada di Desa Adat Peminge, Sawangan, Nusa Dua, Kabupaten Badung, Provinsi Bali. Peta lokasi penelitian dapat ditampilkan pada Gambar 1 .

\subsection{Metode Penelitian}

Penelitian ini dilakukan di Pantai Geger, Nusa Dua, Bali selama 45 hari pemeliharaan. Budidaya rumput laut yang diintegrasikan bersama dengan kerang abalon (Haliotis squamata) menggunakan perlakuan dengan padat tebar yang berbeda yaitu: 20 benih dan 40 benih abalon. Metode yang digunakan adalah metode Rancangan Acak Lengkap (RAL) dengan menggunakan tiga perlakuan dan tiga kali ulangan. Deskripsi variasi perlakuan rumput laut Gracilaria sp dan kerang abalon (Haliotis squamata) yang digunakan adalah sebagai berikut :

T1 = Rumput Laut sebagai kontrol (100 gram)

$\mathrm{T} 2$ = Rumput Laut (100 gram) dan Kerang Abalon (20 benih)

T3 = Rumput Laut (100 gram) dan Kerang Abalon (40 benih)
Berikut rancangan percobaan ditampilkan pada tabel 1.

Tabel 1.

Rancangan Percobaan

\begin{tabular}{cccc}
\hline \multirow{2}{*}{ Perlakuan } & \multicolumn{3}{c}{ Ulangan } \\
\cline { 2 - 4 } & 1 & 2 & 3 \\
\hline T1 (kontrol) & $\mathrm{T}_{11}$ & $\mathrm{~T}_{12}$ & $\mathrm{~T}_{13}$ \\
$\mathrm{~T} 2$ & $\mathrm{~T}_{21}$ & $\mathrm{~T}_{22}$ & $\mathrm{Y}_{23}$ \\
$\mathrm{~T} 3$ & $\mathrm{~T}_{31}$ & $\mathrm{~T}_{32}$ & $\mathrm{~T}_{33}$ \\
\hline
\end{tabular}

\subsection{Tahap Pengumpulan Data}

Pada penelitian ini terdapat dua jenis kontruksi yang digunakan yaitu monokultur dan sistem IMTA. Kontruksi secara monokultur digunakan sebagai kontrol atau tidak terintegrasi antara rumput laut dengan kerang abalon, sedangkan sistem IMTA didesain dengan menggabungkan rumput laut dan kerang abalon. Kerangka kontruksi budidaya menggunakan besi dengan ukuran $157 \mathrm{~cm}$ x $110 \mathrm{~cm}$ x $80 \mathrm{~cm}$. Beberapa metode penanaman yang dikembangkan dalam budidaya rumput laut yaitu metode lepas dasar, metode rakit, metode tali panjang dan metode tali gantung, dalam hal ini metode penanaman juga mempengaruhi pertumbuhan rumput laut (Bindu and Levine, 2011).

Penanaman rumput laut Gracilaria sp pada monokultur menggunakan metode lepas dasar. 
Jarak antar individu rumput laut sebesar $20 \mathrm{~cm}$, satu ris tali berisi 10 sampel rumput laut. Rumput laut yang akan ditanam dilakukan dengan cara digantungkan di atas tali ris dengan menggunakan jaring buah, kemudian diikat dengan kabel tis agar berbentuk kantong. Penanaman rumput laut melalui budidaya IMTA yaitu berada diatas setiap wadah pemeliharaan abalon dengan berjarak $5 \mathrm{~cm}$, jarak masing-masing wadah pemeliharaan kerang abalon $5 \mathrm{~cm}$ dan jarak penanaman antar perlakuan T2 dan T3 sebesar $15 \mathrm{~cm}$. Wadah pemeliharaan kerang abalon menggunakan keranjang buah yang berwarna putih dengan ukuran $48,5 \mathrm{~cm} \times 32 \mathrm{~cm} \times$ $15 \mathrm{~cm}$, keranjang tersebut dilapiskan bambu. Berikut kontruksi budidaya yang digunakan dapat dilihat pada Gambar 2.

Rumput laut Gracilaria sp yang digunakan berasal dari Pantai Geger Nusa Dua, Bali. Rumput laut sebelum ditanam terlebih dulu dilakukan pengukuran dengan cara menimbang berat awal sebesar 100 gram. Penanaman bibit rumput laut dilakukan pada pagi hari dengan menggunakan metode lepas dasar sebanyak 3 unit dan 6 unit dengan penanaman sistem IMTA. Tali ris yang digunakan masing-masing berukuran 2 meter. Rumput laut Gracilaria sp dimasukan kedalam jaring buah yang berukuran $1,5 \mathrm{~mm}$ dan diikat menyerupai kantong.

Kerang abalon $H$. squamata yang dijadikan sebagai organisme yang dibudidayakan sistem IMTA dengan rumput laut, berasal dari Balai Besar Penelitian dan Pengembangan Budidaya Laut (BBPPBL), Gondol, Bali. Benih yang digunakan berukuran panjang cangkang 3,5-4 cm. Jumlah total benih abalon $H$. squamata yang digunakan sebanyak 180, sebelum diintegrasikan bersama rumput laut, terlebih dahulu benih kerang abalon diaklimatiasasi didalam wadah pemeliharaan selama 24 jam, agar dapat beradaptasi dengan lingkungan yang baru ditempati dan ditempatkan dalam wadah diletakkan secara acak. Pemeliharaan kerang abalon dilakukan selama 45 hari, kerang abalon diberikan pakan berupa rumput laut Gracilaria sp secukupnya setiap tiga hari sekali.

Pengukuran pertumbuhan rumput laut Gracilaria sp dilakukan setiap 15 hari. Pengukuran dilakukan dengan menimbang berat rumput laut dengan menggunakan timbangan digital. Masingmasing individu rumput laut ditandai dengan menggunakan nomor. Sampel yang ditimbang sebanyak 10 sampel individu rumput laut dangan 3 perlakuan dan 3 kali ulangan hingga waktu panen (selama 15 hari) sebagian hasil panen akan digunakan sebagai pakan kerang abalon Haliotis squamata dan digunakan sebagai bibit kembali.

Parameter kualitas air yang diukur yaitu parameter fisika dan kimia. Pengukuran kualitas air seperti kecerahan, kedalaman kecepatan arus, suhu, salinitas, derajat keasaman $(\mathrm{pH})$, dan oksigen terlarut (DO) dilakukan secara insitu. Pengukuran parameter kualitas perairan dilakukan pada waktu yang berbeda. Untuk analisis nitrat dan fosfat pada kolom perairan dilakukan di Laboratorium Kesehatan Provinsi Bali.

\subsection{Analisis Data}

Data yang diperoleh dari hasil penelitian dianalisis dengan menggunakan bantuan Microsoft Excel 2010 bertujuan untuk menghitung laju

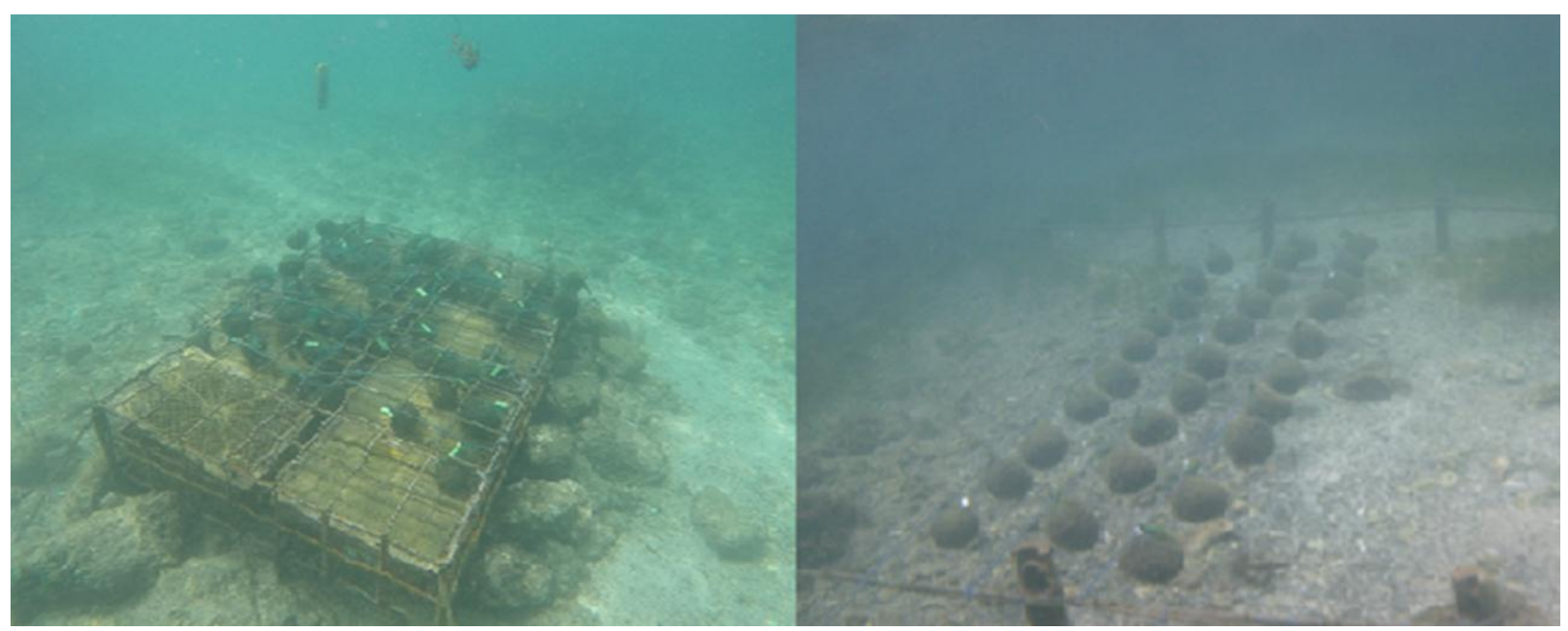

Gambar 2. Kontruksi budidaya rumput laut sistem IMTA dan monokultur 
pertumbuhan serta kelulushidupan rumput laut dan SPSS (Statistical Package for the Social Science) versi 23.0 bertujuan untuk menganalisis uji normalitas dan homogenitas serta ANOVA. Data terlebih dahulu di analisis menggunakan Levene's Test. Uji Levene's digunakan untuk mengetahui apakah data terdistribusi normal pada pertumbuhan rumput laut dan selanjutnya dilakukan uji statistik One Way ANOVA untuk mengetahui apakah ada pengaruh berat rumput laut terhadap perlakuan.

\subsubsection{Laju Pertumbuhan Spesifik}

Laju pertumbuhan spesifik dihitung menggunakan rumus Syahlun et al. (2013) pada persamaan 1 sebagai berikut :

$\mathrm{SGR}=\frac{\ln \mathrm{W}_{\mathrm{t}}-\ln \mathrm{W}_{\mathrm{O}}}{\mathrm{t}} \times 100 \%$

Keterangan :

SGR = Specific Growth Rate/Laju Pertumbuhan Spesifik (\%)

$\ln W_{t}=$ Berat akhir rumput laut (gram)

$\ln W_{\mathrm{o}}=$ Berat awal rumput laut (gram)

$\mathrm{t} \quad=$ Waktu pemeliharaan (hari)

\subsubsection{Kelulushidupan Rumput Laut}

Kelulushidupan rumput laut dihitung dengan menggunakan data awal dan data akhir penelitian. Kelulushidupan rumput laut menurut Yustianti et al. (2013), pada persamaan 2 sebagai berikut:

$\mathrm{SR}=\frac{\mathrm{Nt}}{\mathrm{No}} \times 100 \%$

Keterangan :

$\mathrm{SR}=$ Kelulushidupan rumput laut (\%)

$\mathrm{No}=$ Jumlah individu pada awal penelitian (gram)

$\mathrm{Nt}=$ Jumlah individu pada akhir penelitian (gram)

\subsection{Parameter Lingkungan}

\subsubsection{Kecepatan Arus}

Kecepatan arus perairan dihitung dengan cara selang waktu (t) yang dibutuhkan lagrangian dan jarak tempuh (s) dengan menggunakan rumus menurut Rasyid (2005), pada persamaan 3 adalah sebagai berikut :

$V=\frac{s}{t}$
Keterangan :

$\mathrm{V}=$ Kecepatan arus (m/detik)

$\mathrm{S}=$ Jarak tempuh (meter)

$\mathrm{t}=$ Waktu (detik)

\subsubsection{Kecerahan Perairan}

Kecerahan perairan menggunakan alat ukur secchi disk. Kecerahan perairan dapat dilakukan dengan memasukan secchi disk kedalam perairan, dapat dihitung dengan rumus menurut Effendi (2003) pada persamaan 4 adalah sebagai berikut:

$\mathrm{K}=\frac{\mathrm{d} 1+\mathrm{d} 2}{2} \times 100 \%$

Keterangan :

$\mathrm{K}=$ Kecerahan $(\mathrm{m})$

$\mathrm{d} 1$ = Kedalaman secchi disk saat tidak terlihat

$\mathrm{d} 2$ = Kedalaman secchi disk saat mulai tampak kembali

\subsubsection{Nutrien (nitrat dan fosfat) Pada Perairan}

Analisis nitrat dan fosfat pada sampel air laut di perairan dilakukan di UPT. Balai Laboratorium Kesehatan Provinsi Bali, dengan menggunakan metode brusin untuk menganalisis nitrat dan untuk menganalisis fosfat menggunakan metode amm-molybdat.

\section{Hasil dan Pembahasan}

\subsection{Parameter Lingkungan}

Parameter lingkungan dalam suatu perairan sangat menentukan kelangsungan hidup biota maupun vegetasi yang berada pada lingkungan disekitarnya. Berikut hasil pengukuran kualitas perairan Pantai Geger, ditampilkan pada Tabel 2.

Tabel 2.

Pengukuran Kualitas Air di Lokasi Penelitian

\begin{tabular}{clcc}
\hline No & Parameter & Satuan & Nilai \\
\hline 1 & Suhu & ${ }^{0} \mathrm{C}$ & $27,3-31,5$ \\
2 & Kedalaman & $\mathrm{m}$ & $40-80 \mathrm{~cm}$ \\
3 & Kecerahan & $\%$ & 100 \\
4 & Kecepatan Arus & $\mathrm{m} / \mathrm{s}$ & 0,05 \\
5 & Salinitas & $\mathrm{ppt}$ & $33-35$ \\
6 & Derajat & - & $8,14-8,17$ \\
7 & Keasaman $(\mathrm{pH})$ & & $5,2-5,57$ \\
\hline
\end{tabular}


Tabel 3.

Analisis Nitrat dan Fosfat di Lokasi Penelitian

\begin{tabular}{ccccc}
\hline Parameter & \multicolumn{2}{c}{ Kontruksi } & \multicolumn{2}{c}{ Kontrol } \\
Lingkungan & Awal & Akhir & Awal & Akhir \\
\hline Nitrat $(\mathrm{mg} / \mathrm{l})$ & $<0,010$ & 0,711 & $<0,010$ & 0,603 \\
Fosfat $(\mathrm{mg} / \mathrm{l})$ & 0,611 & 0,152 & 0,911 & 0,044 \\
\hline
\end{tabular}

Berdasarkan hasil pengukuran suhu selama 45 hari pemeliharaan, suhu di perairan berkisar antara $27,3^{\circ} \mathrm{C}-31,5^{\circ} \mathrm{C}$. Menurut Mudeng et al., (2015), bahwa kisaran suhu perairan yang optimal untuk membudidayakan rumput laut yaitu 26$30^{\circ} \mathrm{C}$, sedangkan kualitas suhu yang optimal untuk pemeliharaan kerang abalon berkisar $24^{\circ} \mathrm{C}-30^{\circ} \mathrm{C}$ (Susanto, 2010), sehingga dalam hal ini kisaran suhu yang didapatkan sesuai untuk dilakukan pembudidayaan terintegrasi rumput laut dan kerang abalon di Pantai Geger, namun untuk pertumbuhan rumput laut Gracilaria $s p$ dengan kisaran nilai suhu diatas batas optimal memiliki pertumbuhan lebih lambat tetapi masih dapat ditolerir.

Kecerahan perairan pada lokasi penelitian menunjukkan bahwa tingkat kecerahan sebesar $100 \%$. Kecerahan dengan kisaran 100\% baik untuk pertumbuhan rumput laut dengan perairan yang tidak keruh (sinar matahari dapat menembus hingga dasar perairan) (Abdan et al., 2013), sehingga hasil pengukuran kecerahan pada lokasi penelitian tersebut sesuai untuk pembudidayaan rumput laut.

Kedalaman perairan di lokasi penelitian pada waktu surut berkisar antara $40-80 \mathrm{~cm}$ dari permukaan laut dan pada saat pasang kedalaman dapat mencapai 1-3 meter. Hal ini sesuai dengan pernyataan Menurut Masyahoro dan Mappiratu, (2010), yang menyatakan kedalaman perairan yang baik untuk rumput laut Gracilaria sp 0,5-1,0 m pada surut terendah. Menurut octaviany (2008) umumnya abalon berada pada kedalaman 0-5 m. Berdasarkan hasil pengukuran kedalaman di lokasi penelitian sesuai untuk budidaya rumput laut dan kerang abalon.

Secara visual dasar perairan di lokasi penelitian yang dijadikan sebagai tempat budidaya memiliki jenis substrat pasir berkarang. Hal ini sesuai menurut Litaay (2014), bahwa makroalga dapat tumbuh pada substrat pasir, karang mati dan pecahan karang. Habitat hidup abalon dapat ditemukan pada substrat dasar berupa batuan karang, karena abalon menempel dan bersembunyi pada substrat yang permukaannya keras (Octaviany, 2008), sehingga dalam hal ini substrat yang terdapat di lokasi penelitian tersebut sesuai dengan lokasi tumbuhnya rumput laut Gracilaria sp dan habitat hidupnya kerang abalon H. squamata.

Berdasarkan pengukuran kecepatan arus pada lokasi penelitian yaitu $0,05 \mathrm{~m} /$ detik. Kecepatan arus yang ideal untuk pertumbuhan rumput laut antara (20-40) $\mathrm{cm} /$ detik atau $(0,2-0,4) \mathrm{m} /$ detik (Basmal et al., 2009). Berdasarkan hasil pengukuran maka kondisi arus yang didapatkan berada dibawah dari kisaran ideal, hal ini dikarenakan waktu pengukuran yang dilakukan yaitu pada saat menuju surut.

Salinitas di perairan selama pemeliharaan yaitu berkisar 33 - 35 ppt. Menurut Guo et al. (2014), menyatakan bahwa salinitas optimal untuk pertumbuhan rumput laut berkisar antara 25-33 ppt, sedangkan salinitas yang optimal untuk pemeliharaan abalon berkisar antara $30-35 \mathrm{ppt}$ (Susanto, 2010). Kisaran salinitas yang diperoleh sesuai untuk dilakukan pembudidaya rumput laut, dikarenakan rumput laut Gracilaria $s p$ memiliki tingkat toleransi salinitas yang tinggi, namun untuk pertumbuhan rumput laut dengan kisaran salinitas diatas batas optimal menyebabkan pertumbuhan menjadi lebih lambat, sedangkan untuk kerang abalon kisaran salinitas sudah sesuai.

Kisaran DO pada lokasi penelitan diperoleh antara 5,2 - 5,57 mg/l. Kisaran oksigen terlarut yang diperoleh masih dalam kisaran yang layak terhadap kelangsungan hidup rumput laut Gracilaria sp dan kerang abalon $H$. squamata, namun menurunnya konsentrasi oksigen terlarut dapat mempengaruhi fotosintesis, yang dapat menyebabkan terganggunya pertumbuhan rumput laut. Hal ini sesuai menurut Dahlia et al. (2015), yang menyatakan bahwa nilai oksigen terlarut untuk rumput laut adalah lebih dari 5 $\mathrm{mg} / \mathrm{l}$, sedangkan kadar oksigen terlarut yang sesuai dalam pemeliharaan kerang abalon adalah lebih dari 5 mg/l (Nurfajrie et al., 2014).

Derajat keasaman $(\mathrm{pH})$ berkisar antara 8,148,17 . Kondisi $\mathrm{pH}$ tersebut masih relatif stabil dan masih berada dalam batas optimum, dalam mendukung kelangsungan hidup pertumbuhan rumput laut Gracilaria $s p$ dan kerang abalon $H$. squamata. Hal ini sesuai dengan pernyataan Ain et 


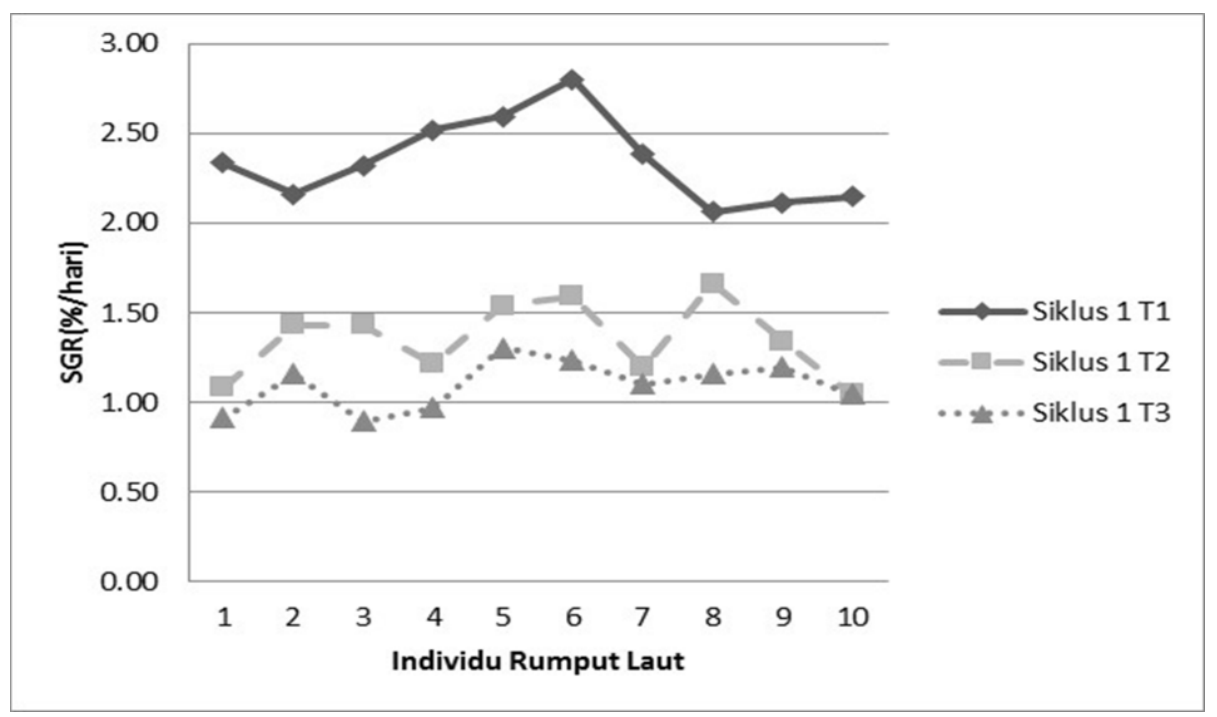

Gambar 3. Grafik laju pertumbuhan spesifik rumput laut pada siklus 1

al., (2014), menambahkan bahwa hampir seluruh makroalga menyukai kisaran pH 6,8 - 9,6, dengan pH optimum 8,2 - 8,7 dan menurut Cook and Gordon (2010), bahwa pH yang optimal bagi budidaya kerang abalon berkisar antara 7,5 - 8,7.

Kadar nitrat yang terukur di lokasi budidaya pada sistem IMTA yang terdapat pada kontruksi dan monokultur yang terdapat pada kontrol, menunjukkan nilai yang didapatkan diawal penelitian yaitu $<0,01 \mathrm{mg} / \mathrm{l}$ dan akhir pemeliharaan sebesar 0,603 mg/l pada kontrol dan 0,711 mg/l pada kontruksi. Menurut Dahlia et al. (2015), menyatakan bahwa kisaran nitrat untuk pertumbuhan rumput laut terendah sebesar 0,3$0,9 \mathrm{mg} / \mathrm{l}$, sedangkan kisaran nitrat untuk pertumbuhan yang optimal adalah 0,9-3,5 mg/l, sedangkan menurut Keputusan Menteri Lingkungan Hidup No.51 Tahun 2004 konsentrasi nitrat untuk biota laut adalah 0,008 mg/l (MNLH, 2004). Hasil analisis nitrat yang diperoleh termasuk kedalam jenis kisaran nitrat yang rendah untuk pertumbuhan rumput laut dan untuk biota laut termasuk dalam kisaran tinggi.

Kadar fosfat yang terukur di lokasi budidaya pada sistem IMTA yang terdapat pada kontruksi dan monokultur yang terdapat pada kontrol, menunjukkan nilai yang didapatkan di awal penelitian sebesar 0,611 $\mathrm{mg} / \mathrm{l}$ pada kontrusksi dan 0,911 mg/l pada kontrol, sedangkan di akhir penelitian sebesar 0,1524 $\mathrm{mg} / \mathrm{l}$ pada kontruksi dan 0,0442 mg/l pada kontrol. Menurut Khasanah (2013), bahwa kadar fosfat yang optimal untuk budidaya rumput laut berkisar antara 0,051-1 mg/l. Baku mutu untuk kehidupan biota laut menurut
Keputusan Menteri Lingkungan Hidup (KMLH) No.51 Tahun 2004 adalah 0,015 mg/l (MNLH, 2004). Kisaran kadar fosfat yang diperoleh masih dalam kisaran yang optimal untuk pertumbuhan rumput laut.

\subsection{Laju Pertumbuhan Spesifik}

3.2.1. Laju Pertumbuhan Spesifik Rumput Laut Siklus 1

Hasil perhitungan laju pertumbuhan spesifik yang didapat dari rata-rata pertumbuhan selama 15 hari pada siklus 1 (panen ke-1) dari 3 perlakuan yang ada, ditampilkan pada Gambar 3.

Berdasarkan grafik SGR rumput laut pada siklus 1, menunjukkan perlakuan T1 nilai individu rumput laut tertinggi nomor enam sebesar 2,81\%/hari dan terendah nomor delapan sebesar 2,07\%/hari. Pada perlakuan T2 nilai individu rumput laut tertinggi nomor delapan sebesar $1,66 \% /$ hari dan terendah nomor sepuluh sebesar 1,05\%/hari. Perlakuan T3 nilai individu rumput laut tertinggi pada nomor lima sebesar 1,31\%/hari dan individu rumput laut terendah nomor tiga sebesar $0,89 \% /$ hari.

Berdasarkan hal tersebut budidaya rumput laut melalui IMTA dari hasil penelitian menunjukkan pertumbuhan rumput laut yang lebih tinggi pada kontrol dibandingkan dengan budidaya IMTA. Hal ini berbanding terbalik dengan hasil penelitian Huo et al., (2012), yang menyatakan adanya keuntungan dengan mengkombinasikan budidaya alga merah Gracilaria verrucosa dengan ikan 
diperairan Timur Laut Cina, biomassa rumput laut mengalami peningkatan 42 kali lipat dibandingkan dengan biomassa awal dan hasil penelitian Sukti et al. (2016), bahwa pemeliharaan abalon bersama sponge dan rumput laut baik dalam menunjang pertumbuhan dan sintasannya.

Perbedaan tersebut diduga dipengaruhi oleh banyak predator atau pemangsa seperti ikan yang berada di kontruksi tersebut yang digunakan sebagai tempat bersembunyi ataupun sebagai tempat tinggal bagi ikan-ikan, dikarenakan jarak antara rumput laut yang ditanam diatas kontruksi abalon terlalu dekat. Hal ini memudahkan predator seperti ikan memakan rumput laut tersebut, sehingga mempengaruhi berat rumput laut Gracilaria sp yang menyebabkan pertumbuhan rumput laut menurun pada lokasi budidaya IMTA. Hal ini sesuai dengan hasil penelitian Andreas et al. (2017), yang menyatakan bahwa serangan ikan pemangsa rumput laut masih menjadi faktor penghambat pertumbuhan rumput laut.

3.2.2. Laju Pertumbuhan Spesifik Rumput Laut Siklus 2

Hasil perhitungan laju pertumbuhan spesifik yang didapat dari rata-rata pertumbuhan selama 15 hari pada siklus 2 (panen ke-2) dibandingkan antar perlakuan, ditampilkan pada Gambar 4.

Berdasarkan grafik diatas menunjukkan pertumbuhan rumput laut Gracilaria sp lebih tinggi pada perlakuan T1 (kontrol) dibandingkan dengan perlakuan T2 dan T3. Hasil yang didapatkan dari siklus 2 perlakuan T1, nilai individu rumput laut tertinggi pada nomor tujuh yaitu 2,64\%/hari dan terendah nomor tiga yaitu 2,03\%/hari. Perlakuan $\mathrm{T} 2$ individu rumput laut tertinggi nomor dua yaitu $1,63 \% /$ hari dan terendah nomor lima yaitu 1,05\%/hari, sedangkan perlakuan T3 nilai individu rumput laut tertinggi pada nomor sepuluh yaitu $1,45 \% /$ hari dan terendah nomor enam yaitu $0,91 \% /$ hari.

Berdasarkan hal tersebut budidaya rumput laut melalui IMTA dari hasil penelitian menunjukkan pertumbuhan rumput laut yang lebih tinggi pada kontrol dibandingkan dengan budidaya IMTA. Hal ini berbeda dari penelitian yang dilakukan oleh Yuniarsih et al. (2014), yang menyatakan bahwa peningkatan berat rata-rata pertumbuhan rumput laut pada lokasi budidaya IMTA lebih tinggi dibandingkan dengan rumput laut kontrol, yang disebabkan oleh adanya rumput laut yang dapat mengasimilasi nitrogen inorganik yang terlarut menjadi bahan organik melalui proses fotosintesis bagi pertumbuhan rumput laut yang berada di lokasi budidaya IMTA. Perbedaan tersebut diduga karena dipengaruhi dari persaingan dalam memperoleh unsur hara dan endapan yang menempel pada jaring serta thallus rumput laut sehingga dapat menghambat proses fotosintesis.

Terdapatnya hewan-hewan pada thallus rumput laut dapat terganggunya pertumbuhan rumput laut yang nantinya dapat menyebabkan pertumbuhan mengalami penurunan. Hal ini sesuai menurut Yulianto dan Mira (2009), bahwa terdapatnya hewan-hewan yang menempel pada thallus Gracilaria sp ditandai dengan terpotongnya bagian thallus tanaman rumput laut yang

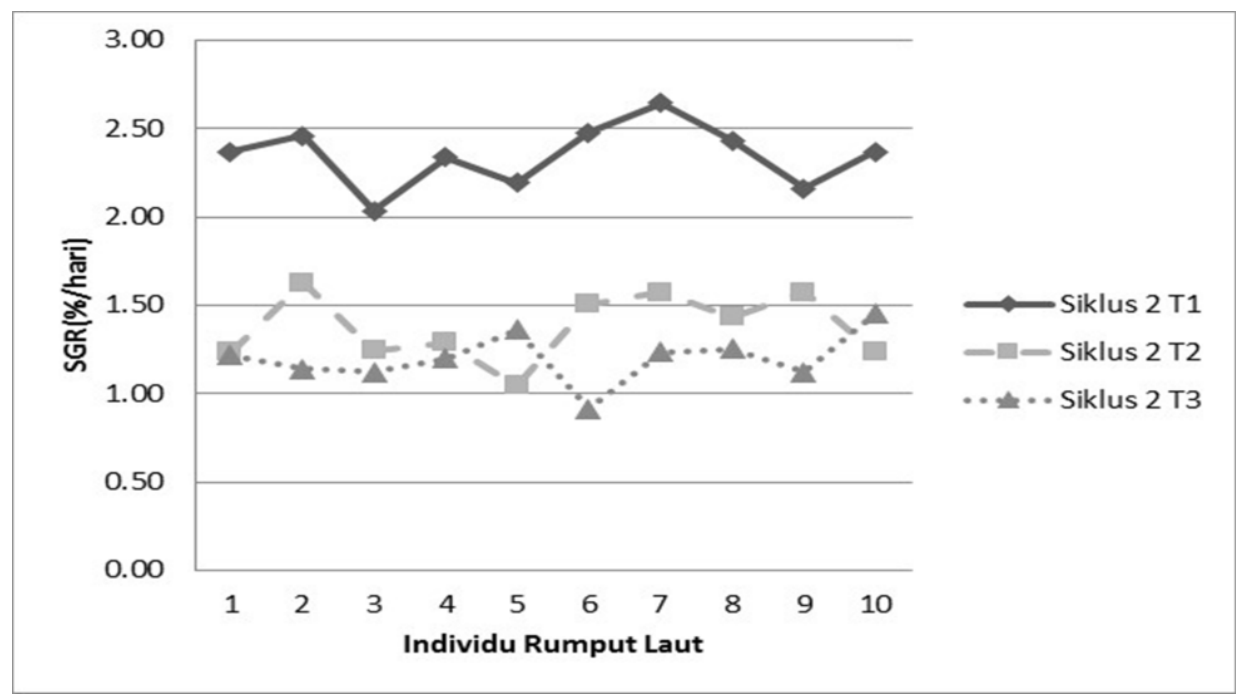

Gambar 4. Grafik laju pertumbuhan spesifik rumput laut pada siklus 2 
menyebabkan pertumbuhan rumput laut tiap minggunya semakin menurun. Hal ini juga diduga karena adanya predator disekitar kontruksi dan adanya kompetitor dari tumbuhan lain seperti gulma pada kontruksi, sehingga mempengaruhi pertumbuhan rumput laut.

Penerapan budidaya menggunakan sistem jaring dapat mempengaruhi pertumbuhan dan perkembangan rumput laut dalam proses fotosintesis, memanfaatkan $\mathrm{CO}_{2}$, air dan cahaya matahari serta molekul klorofil, untuk menghasilkan senyawa karbohidrat dan oksigen. Terjadinya peningkatan konsentrasi karbondioksida pada lingkungan perairan, dapat menyebabkan peningkatan aktifitas fotosintesis, sehingga laju pertumbuhan dalam budidaya rumput laut meningkat, selain dipengaruhi oleh fotosintesis, rumput laut juga dipengaruhi oleh faktor internal dan eksternal. Faktor internal tersebut berupa keadaan thallus yang digunakan, sedangkan faktor eksternal berupa keadaan lingkungan perairan baik fisika maupun kimia yang mempengaruhi pertumbuhan rumput laut (Darmawati, 2013).

3.2.3. Laju Pertumbuhan Spesifik Rumput Laut Siklus 3

Hasil perhitungan laju pertumbuhan spesifik yang didapat dari rata-rata pertumbuhan selama 15 hari pada siklus 3 (panen ke-3) dibandingkan antar perlakuan, dapat dilihat pada Gambar 5.

Laju pertumbuhan rumput laut Gracilaria $s p$ dari grafik tersebut menunjukkan hasil yang diperoleh pada masing-masing perlakuan $\mathrm{T} 1$ nilai individu rumput laut tertinggi nomor delapan yaitu $2,54 \%$ /hari, terendah nomor sembilan yaitu 2,08\%/hari, untuk perlakuan T2 nilai individu rumput laut tertinggi nomor tujuh yaitu $1,56 \% /$ hari, terendah nomor enam yaitu 1,22\%/hari, sedangkan perlakuan T3 individu rumput laut tertinggi pada nomor satu yaitu $1,45 \% /$ hari dan terndah nomor sembilan yaitu $1,10 \% /$ hari. Berdasarkan penelitian yang dilakukan nilai laju pertumbuhan rumput laut lebih tinggi di lokasi kontrol dibandingkan dengan di lokasi budidaya IMTA, sehingga pertumbuhan rumput laut pada siklus 1 , siklus 2 dan siklus 3 menunjukkan pertumbuhan lebih tinggi pada perlakuan kontrol, dalam hal ini terjadi perbedaan dari konsep IMTA yang semestinya pertumbuhan rumput laut lebih optimal pada sistem budidaya tersebut dikarenakan adanya pengaruh dari tempat pemeliharaan yang terintegrasi kurang mendukung untuk pertumbuhan rumput laut.

Selama pemeliharaan pertumbuhan rumput laut di siklus 3 mengalami penurunan kualitas air yang disebabkan perubahan kondisi cuaca yang mempengaruhi kondisi lingkungan perairan. Meningkatnya curah hujan menyebabkan terjadinya kekeruhan perairan dan tidak adanya cahaya matahari yang masuk ke dasar perairan yang mengakibatkan proses fotosintesis terganggu. Kondisi lingkungan perairan seperti suhu juga mempengaruhi proses terjadinya fotosintesis. Laju fotosintesis akan meningkat pada suhu optimum namun ketika suhu melewati batas optimum maka akan terjadi penurunan laju fotosintesis yang akan mempengaruhi pertumbuhan dan perkembangan rumput laut.

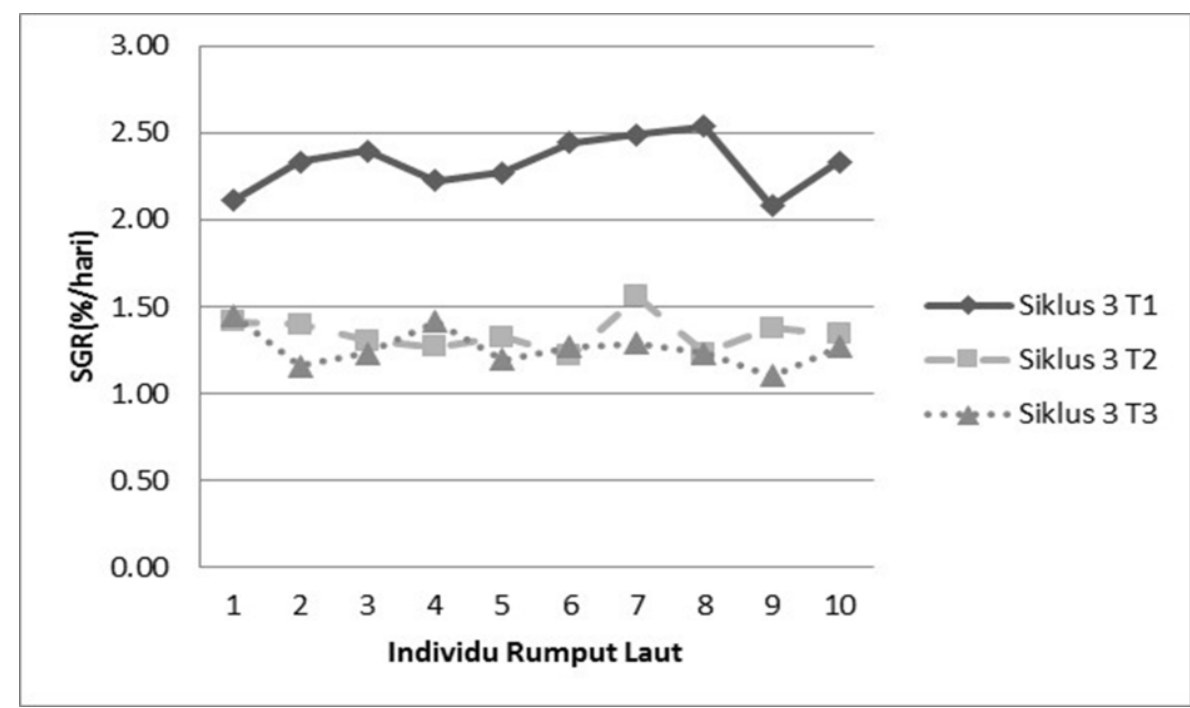

Gambar 5. Grafik laju pertumbuhan spesifik rumput laut pada siklus 3 
Fotosintesis merupakan reaksi yang memerlukan enzim, sedangkan kinerja enzim dipengaruhi oleh suhu (Yudasmara, 2014). Hasil pengukuran suhu pada akhir pemeliharaan terjadinya peningkatan, sehingga dalam hal ini diduga terjadinya penurunan laju fotosintesis dan dapat mempengaruhi pertumbuhan serta perkembangan rumput laut.

Terjadinya peningkatan suhu diperairan juga mempengaruhi konsentrasi oksigen terlarut diperairan. Oksigen diperairan berasal dari proses difusi dan hasil fotosintesis tanaman air, sehingga dalam hal ini hasil pengukuran oksigen terlarut yang menurun pada akhir pemeliharaan mempengaruhi proses fotosintesis yang dapat menyebabkan terganggunya laju pertumbuhan rumput laut. Menurut Darmawati (2013), bahwa terdapat faktor yang mempengaruhi dalam pembudidayaan rumput laut diantaranya adalah arus, kondisi dasar perairan, kedalaman, salinitas, kecerahan, suhu, cahaya matahari, nutrien, pencemaran dan ketersediaan bibit yang mempengaruhi pertumbuhan rumput laut.

Menurut Ferawati et al, (2014), bahwa rumput laut tidak dapat dibedakan baik akar, batang maupun daun, sehingga bagian tubuh disebut thallus memerlukan cahaya matahari untuk proses fotosintesis dan membutuhkan nutrien untuk membantu pertumbuhan rumput laut. Melalui proses ini rumput laut menyerap $\mathrm{CO}_{2}$ dan $\mathrm{H}_{2} \mathrm{O}$ serta molekul kompleks nutrien dari lingkungan. Pada saat membudidayakan rumput laut membutuhkan perairan yang tingkat kekeruhannya rendah, sehingga energi dari cahaya matahari dapat masuk ke perairan secara optimal untuk mendukung proses fotosintesis terhadap pertumbuhan rumput laut.

Hasil analisis ANOVA pada berat rumput laut pada siklus 1, siklus 2 dan siklus 3 dari perlakuan T1, T2 dan T3 diketahui bahwa nilai sig $=0,000<\alpha$ $=0,05$, sehingga dapat disimpulkan bahwa perbedaan pemberian perlakuan menyebabkan perbedaan berat rumput laut.

\subsection{Kelulushidupan Rumput laut}

Kelulushidupan (survival rate) merupakan persentase tingkat kelangsungan hidup, dengan menghitung jumlah rumput laut yang hidup selama waktu pemeliharaan dibandingkan dengan jumlah rumput laut pada awal pemeliharaan. Berikut ditampilkan tingkat kelulushidupan rumput laut pada siklus 1 , siklus 2 dan siklus 3 pada Gambar 6.

Tingkat kelangsungan hidup rumput laut Gracilaria sp pada siklus 1 dan siklus 3, memiliki tingkat kelangsungan hidup yang tinggi yaitu $100 \%$ pada setiap perlakuan. Sedangkan kelulushidupan rumput laut pada siklus 2 selama pemeliharaan berlangsung menunjukkan tingkat kelangsungan hidup rumput laut rendah pada perlakuan T2 yaitu sebesar $90 \%$ dan tinggi pada perlakuan T1 dan T3 yaitu sebesar 100\%. Terjadinya penurunan kelulushidupan pada siklus 2 di perlakuan T2 dikarenakan oleh hilangnya 1 individu rumput yang disebabkan terlepasnya ikatan pada jaring rumput laut, sehingga rumput laut terbawa oleh arus.

Tingkat kelangsungan hidup juga dipengaruhi oleh kondisi perairan pada lokasi penelitian, jika

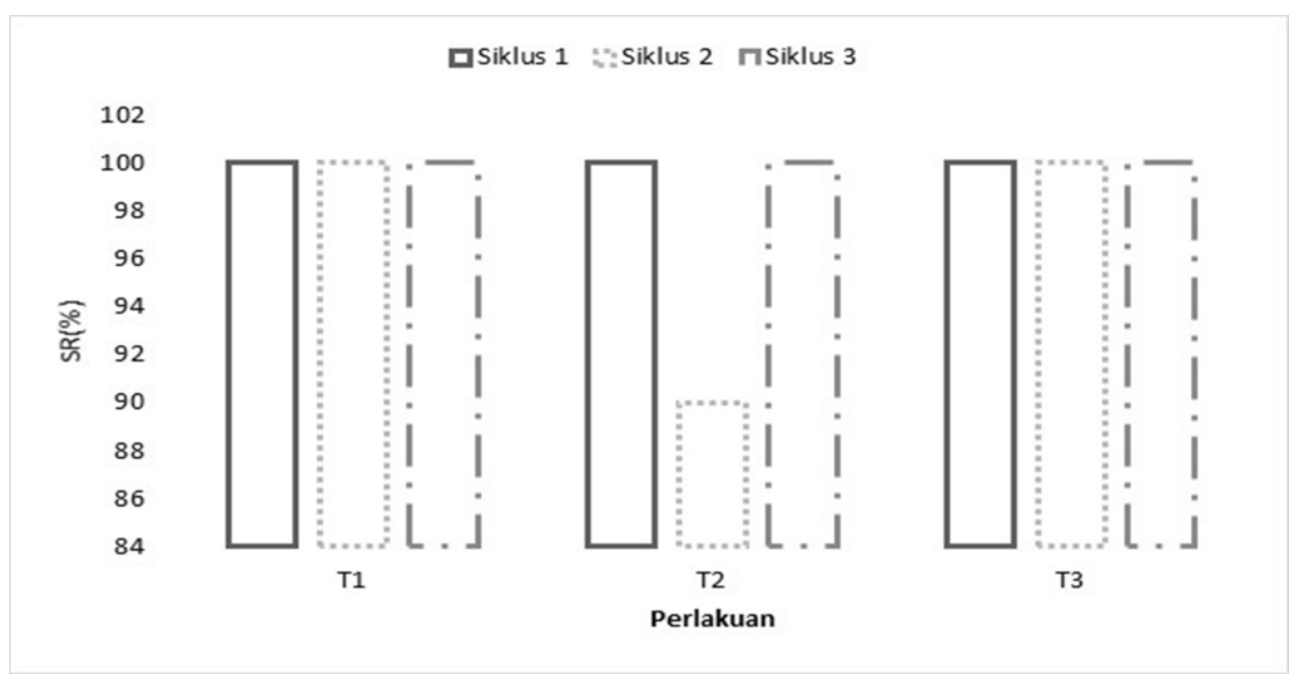

Gambar 6. Grafik kelulushidupan rumput laut siklus 1, 2 dan 3 
kondisi kualitas perairannya sesuai dengan kondisi perairan yang dibutuhkan rumput laut, maka pertumbuhan rumput laut akan optimal dan tingkat kelangsungan hidupnya tinggi. Kelulushidupan rumput laut tergantung dari besarnya penetrasi cahaya matahari yang diterima oleh rumput laut yang mempengaruhi keadaan thallus dan kuatnya arus yang menyebabkan thallus patah atau rontok. Dalam hal ini mengindikasikan bahwa penerapan pemeliharaan rumput laut menggunakan sistem jaring dapat meminimalisir adanya rumput laut yang hilang terbawa arus, sehingga tingkat kelulushidupannya tinggi.

Panen rumput laut yang dilakukan setiap 15 hari sekali juga bertujuan untuk menghindari adanya pembusukan pada rumput laut yang akan menyebabkan kematian. Hal ini dikarenakan pembudidayaan rumput laut menggunakan sistem jaring, dimana thallus pada rumput laut tidak dapat berkembang dengan optimal karena ukuran lubang jaring yang kecil, adanya persaingan antara thallus sehingga nutrisi yang diperoleh rumput laut sedikit. Hal ini sesuai dengan pernyataan Xia et al., (2012) dan Yong et al., (2013), bahwa endapan sedimen atau lumpur yang menempel pada thallus dapat menyebabkan persaingan antar thallus dalam hal kebutuhan cahaya matahari dan nutrien yang diterima, karena tertutup oleh endapan tersebut, sehingga tidak menguntungkan dalam budidaya rumput laut.

\section{Simpulan}

Berdasarkan hasil penelitian Kondisi perairan Pantai Geger terhadap parameter lingkungan fisika dan kimia mendukung budidaya terintegrasi terhadap pertumbuhan rumput laut Gracilaria $s p$ dan kerang abalon H.squamata. Hasil laju pertumbuhan spesifik rumput laut pertumbuhan tertinggi berada pada rumput laut kontrol jika dibandingkan dengan rumput laut yang dibudidayakan sistem IMTA, dikarenakan kontruksi tempat pemeliharaan yang terintegrasi dan penerapan jaring buah yang digunakan dalam pembudidayaan rumput laut kurang optimal dalam pertumbuhan rumput laut. Tingkat kelulushidupan rumput laut pada siklus 1, siklus 2 dan siklus 3 cukup tinggi sebesar 90\%-100\%, dikarenakan penerapan dalam pemeliharaan rumput laut menggunakan jaring buah dapat meminimalisir adanya rumput laut yang hilang terbawa oleh arus.

Berdasarkan hasil penelitian ini disarankan dilakukan penelitian lanjutan menggunakan jenis rumput laut yang berbeda dengan tidak menggunakan jaring dalam budidaya terintegrasi bersama kerang abalon, agar pertumbuhan rumput laut dapat lebih optimal dan kontruksi yang digunakan pada budidaya rumput laut terintegrasi lebih diperhatikan dalam kebersihan tempat pemeliharaan, sehingga menunjang pertumbuhan rumput laut yang lebih optimal.

\section{Ucapan terimakasih}

Penulis mengucapkan terimakasih kepada Dosen penguji Ibu Dr.Sc.Widiastuti,S.Kel.,M.Si, Bapak I Wayan Gede Astawa Karang,S.Si.,M.Si.Ph.D dan Bapak I Nyoman Giri Putra,S.Pd.,M.Si, serta Bapak Made Simbik dan Bapak Made Kutir yang telah memberikan fasilitas tempat serta membantu selama penelitian dilapangan.

\section{Daftar Pustaka}

Abdan, A., Rahman, A., \& Ruslaini, R. (2013). Pengaruh jarak Tanam Terhadap Pertumbuhan dan Kandungan Karagenan Rumput Laut (Eucheuma spinosum) Menggunakan Metode Long Line. Jurnal Mina Laut Indonesia, 3(12), 113-123.

Abreu, M. H., Varela, D. A., Henríquez, L., Villarroel, A., Yarish, C., Sousa-Pinto, I., \& Buschmann, A. H. (2009). Traditional vs. integrated multi-trophic aquaculture of Gracilaria chilensis CJ Bird, J. McLachlan \& EC Oliveira: productivity and physiological performance. Aquaculture, 293(3), 211-220.

Ain, N., Ruswahyuni, R., \& Widyorini, N. (2014). Hubungan Kerapatan Rumput Laut dengan Substrat Dasar Berbeda di Perairan Pantai Bandengan, Jepara. Management of Aquatic Resources Journal, 3(1), 99-107.

Andreas, P. T., Dirgayusa I. G. N. P., \& Puspitha N. L. P. R. (2017). Studi Pertumbuhan Rumput Laut Jenis Kotoni (Eucheuma cottonii) dengan Menggunakan Metode Kurung Dasar dan Lepas Dasar di Perairan Geger, Bali. Journal of Marine and Aquatic Sciences, 3(1), 47-58.

Basmal, J., Utomo, B. S. B., \& Sedayu, B. B. (2009). Mutu Semi Refined Carraeenan (SCR) yang Didaur Ulang. Jurnal Pasca Panen dan Bioteknologi Kelautan dan Perikanan, 4, 1-11.

Bindu, M. S., \& Levine, I. A. (2011). The commercial red seaweed Kappaphycus alvarezii-an overview on farming and environment. Journal of Applied Phycology, 23(4), 789-796. 
Cook, P. A., \& Gordon, H. R. (2010). World abalone supply, markets, and pricing. Journal of Shellfish Research, 29(3), 569-571.

Dahlia, I., Rejeki, S., \& Susilowati, T. (2015). Pengaruh Dosis Pupuk Dan Substrat Yang Berbeda Terhadap Pertumbuhan Caulerpa lentillifera. Journal of Aquaculture Management and Technology, 4(4), 28-34.

Effendi, H. (2003). Telaah Kualitas Air bagi Pengelolaan Sumber Daya dan Lingkungan Perairan. Cetakan Kelima. Yogjakarta: Kanisius.

Ferawati, E., Widyartini, D. S., \& Insan, I. (2014). Studi Komunitas Rumput Laut Pada Berbagai Substrat Di Perairan Pantai Permisan Kabupaten Cilacap. Scripta Biologica, 1(1), 57-62.

Oryza, D., Mahanal, S., \& Sari, M. S. (2017). Identifikasi Rhodophyta Sebagai Bahan Ajar Di Perguruan Tinggi. Jurnal Pendidikan: Teori, Penelitian, dan Pengembangan, 2(3), 309-314.

FAO. (2015). Global Aquaculture Production statistics database updated to 2013: Summary information. Fisheries and Aquaculture Department. Rome, Italy: Fisheries and Aquaculture Department, Food and Agriculture Organization of the United Nations.

Guo, H., Yao, J., Sun, Z., \& Duan, D. (2015). Effect of temperature, irradiance on the growth of the green alga Caulerpa lentillifera (Bryopsidophyceae, Chlorophyta). Journal of applied phycology, 27(2), 879885.

Hasan, M. R., Rejeki, S., \& Ariyati, R. W. (2015). Pengaruh Bobot Awal Yang Berbeda Terhadap Pertumbuhan Gracilaria sp. Yang Dibudidayakan Dengan Metode Longline Di Perairan Tambak Terabrasi Desa Kaliwlingi Kabupaten Brebes. Journal of Aquaculture Management and Technology, 4(2), 92-99.

Mudeng, J. D., Kolopita, M. E., \& Rahman, A. (2015). Kondisi Lingkungan Perairan Pada Lahan Budidaya Rumput Laut Kappaphycus alvarezii Di Desa Jayakarsa Kabupaten Minahasa Utara. e-Journal Budidaya Perairan, 3(1), 172-186.

Khasanah, U. (2013). Analisis Kesesuaian Perairan untuk Lokasi Budidaya Rumput Laut Eucheuma Cottonii di Perairan Kecamatan Sajoanging Kabupaten Wajo. Jurnal Ilmu Kelautan, 14(3), 164-169.

MNLH. (2004). Keputusan Menteri Negara Lingkungan Hidup Nomor 51 Tahun 2004 tentang Baku Mutu Air Laut. Jakarta, Indonesia: Menteri Negara Lingkungan Hidup Republik Indonesia.

Litaay, C. (2014). Sebaran dan Keragaman Komunitas Makro Algae di Perairan Teluk Ambon. Jurnal Ilmu dan Tekonologi Kelautan Tropis, 6(1), 131-142.

Tassakka, A. C. M. A., Latama, G., \& Rustam, R. (2016). Pengaruh Perbedaan Varietas Rumput Laut (Kappaphycus sp) dan Variasi Kedalaman Terhadap Pertumbuhan dan Produksi Rumput Laut Menggunakan Metode Budidaya "Top Down".
TORANI: Jurnal Ilmu Kelautan dan Perikanan, 24(1), 131-142.

Masyahoro, M., \& Mappiratu, M. (2012). Respon Pertumbuhan Pada Berbagai Kedalaman Bibit Dan Umur Panen Rumput Laut Eucheuma cottonii Di Perairan Teluk Palu. Media Litbang Sulteng, 3(2), 104111.

Nobre, A. M., Robertson-Andersson, D., Neori, A., \& Sankar, K. (2010). Ecological-economic assessment of aquaculture options: comparison between abalone monoculture and integrated multi-trophic aquaculture of abalone and seaweeds. Aquaculture, 306(1), 116-126.

Nurfajrie, N., Suminto, S., \& Rejeki, S. (2014). Pemanfaatan Berbagai Jenis Makroalga Untuk Pertumbuhan Abalon (Haliotis squamata) Dalam Budidaya Pembesaran. Journal of Aquaculture Management and Technology, 3(4), 142-150.

Octaviany, M. J. (2008). Beberapa Catatan Tentang Aspek Biologi dan Perikanan Abalon. Oseana, 32(4), 39-47.

Rasyid, A. J. (2005). Studi Kondisi Fisika Oseanografi untuk Kesesuaian Budidaya Rumput Laut di Perairan Pantai Sinjai Timur. Jurnal Torani, 15(2), 73-80.

Hasibuan, S. (2015). Pemetaan Dan Strategi Pemanfaatan Teknologi Pada Industri Olahan Rumput Laut Indonesia Yang Berkelanjutan. Jurnal Operations Excellence, 7(1), 64-81.

Sukti, A. N., Effendy, I. J., \& Sarita, A. H. (2016). Perbandingan Pertumbuhan Dan Sintasan Populasi Abalon Yang Dipelihara Bersama Sponge Dan Rumput Laut. Media Akuatika: Jurnal Ilmiah Jurusan Budidaya Perairan, 1(1), 11-18.

Susanto, B., Rusdi, I., Rahmawati, R., Giri, I. N. A., Sutarmat, T., \& Laut, B. B. R. P. B. (2010). Aplikasi Teknologi Pembesaran Abalon (Haliotis squamata) dalam Menunjang Pemberdayaan Masyarakat Pesisir. In Prosiding Forum Inovasi Teknologi Akuakultur 2010. Bandar Lampung, Indonesia, 20-23 April 2010. (pp. 295-305).

Syahlun, S., Rahman, A., \& Ruslaini, R. (2013). Uji Pertumbuhan Rumput Laut (Kappaphycus alvarezii) Strain Coklat dengan Metode Vertikultur. Jurnal Mina Laut Indonesia, 1(1), 122-132.

Putro, S. P., Widowati, W., Suhartana, S., \& Muhammad, F. (2015). The application of integrated multi trophic aquaculture (IMTA) using stratified double net rounded cage (SDFNC) for aquaculture sustainability. International Journal of Science and Engineering, 9(2), 8589.

Troell, M., Joyce, A., Chopin, T., Neori, A., Buschmann, A. H., \& Fang, J. G. (2009). Ecological engineering in aquaculture-potential for integrated multi-trophic aquaculture (IMTA) in marine offshore systems. Aquaculture, 297(1), 1-9. 
Xia, S., Yang, H., Li, Y., Liu, S., Zhou, Y., \& Zhang, L. (2012). Effects of different seaweed diets on growth, digestibility, and ammonia-nitrogen production of the sea cucumber Apostichopus japonicus (Selenka). Aquaculture, 338, 304-308.

Yong, Y. S., Yong, W. T. L., \& Anton, A. (2013). Analysis of formulae for determination of seaweed growth rate. Journal of applied phycology, 25(6), 1831-1834.

Yudasmara, G. A. (2014). Budidaya Anggur Laut (Caulerpa racemosa) melalui Media Tanam Rigid Quadrant Nets Berbahan Bambu. JST (Jurnal Sains dan Teknologi), 3(2), 468-473.

Yulianto, K., \& Mira S. (2009). Budidaya Makro Aalga Kappaphycus alvarezii (Doty) Secara Vertikal dan
Fejala Penyakit "Ice-ice" di Perairan Pulau Pari. Oseanologi dan Limnologi di Indonesia, 35(3), 325-334.

Yuniarsih, E., Nirmala, K., \& Radiarta, I. N. (2014).

Tingkat Penyerapan Nitrogen Dan Fosfor Pada Budidaya Rumput Laut Berbasis IMTA (Integrated Multi-Trophic Aquaculture) Di Teluk Gerupuk, Lombok Tengah, Nusa Tenggara Barat. Jurnal Riset Akuakultur, 9(3), 487-500.

Yustianti, Y., Ibrahim, M. N., \& Ruslaini, R. (2013). Pertumbuhan dan Sintasan Larva Udang Vaname (Litopenaeus vannamei) Melalui Substitusi Tepung Ikan dengan Tepung Usus Ayam. Jurnal Mina Laut Indonesia, 1(1), 93-103.

(C) 2017 by the authors; licensee Udayana University, Indonesia. This article is an open access article distributed under the terms and conditions of the Creative Commons Attribution license (http://creativecommons.org/licenses/by/3.0/). 